\title{
Simultaneous detection of Brazilian isolates of grapevine viruses by TaqMan real-time RT-PCR
}

\author{
Carla R. Dubiela ${ }^{1,2}$, Thor V.M. Fajardo², Eliezer R. Souto ${ }^{1}$, Osmar Nickel ${ }^{2}$, Marcelo Eiras $^{3} \&$ Luís $^{2}$ \\ Fernando Revers ${ }^{2}$
}

'Departamento de Agronomia, Universidade Estadual de Maringá, 87020-900, Maringá, PR, Brazil; Embrapa Uva e Vinho, 95700-000, Bento Gonçalves, RS, Brazil; ${ }^{3}$ Instituto Biológico, 04014-002, São Paulo, SP, Brazil

Author for correspondence: Thor V.M. Fajardo, e-mail: thor.fajardo@embrapa.br

\begin{abstract}
The aim of this work was to evaluate the efficiency of real-time RT-PCR for detection of different isolates of ten important virus species that infect grapevines in Brazil: Grapevine leafroll-associated virus (GLRaV-1, -2, -3 and -5), Grapevine virus A (GVA), Grapevine virus B (GVB), Grapevine virus D (GVD), Grapevine rupestris stem pitting-associated virus (GRSPaV), Grapevine fleck virus (GFkV) and Grapevine fanleaf virus (GFLV). The reactions consisted of individual (simplex) and simultaneous (duplex) virus detections. Thirty six grapevine accessions, regenerated after thermotherapy and tissue culture treatments, have been analysed. All the above-mentioned viruses were sensitively detected in simplex reactions in samples infected with different virus isolates. Specifically to GLRaV-1 it was necessary to mix reagents refered by different sources to achieve the amplification. GVA, GRSPaV, GLRaV-2 and GLRaV-3 combined with GVB, GFLV, GFkV, GVD and GLRaV-5 were accurately detected in duplex trials. It was shown, that real-time RT-PCR (TaqMan) is able to efficiently detect different local virus species and isolates.
\end{abstract}

Key words: Betaflexiviridae, Closteroviridae, Vitis, diagnostic assays, probes.

Grapevine viruses occur in all grapevine-growing regions of the world, with significant economic impact and relevance in many countries. Among the damages caused by viruses, the reduction in productivity and quality of grapes, and the shortening of the productive life of the vineyard stand out. So far, at least 60 virus species are known to infect grapevines (Vitis spp.) (Martelli, 2012).

The vegetative propagation of the grapevine favors the spread and promotes the development of complex of diseases and accumulation of different virus species/ strains in the same plant. The most efficient control of viruses consists of using virus-free mother plants for plant propagation. Consequently, detection of these viruses is currently an important component of many phytosanitary certification programs for grapevines. Serological methods such as ELISA appear reliable only during a short period of the year because they lack sensitivity for detecting low virus concentrations in dormant woody material. Molecular techniques such as reverse transcription polymerase chain reaction (RT-PCR) can surpass ELISA in sensitivity for detection of some viruses in dormant grapevines. However, this method requires gel electrophoresis analysis for its interpretation and this post-detection step has hampered the routine use of the RT-PCR technique (Marbot et al., 2004).

TaqMan assays are based on the polymerase chain reaction, but additionally utilize the fluorescent detection chemistry. During amplification the dual fluorescent labeled TaqMan probe is cleaved by Taq DNA polymerase, separating the dyes and resulting in an increase in detectable reporter fluorescence in each cycle, corresponding to the amount of product amplified which is monitored in realtime during amplification. The fluorescence emitted after the events of pairing and degradation of the TaqMan probe is considered a very sensitive method to determine the presence of specific sequences. The advantage of this system is based on the nucleotide probe specificity, which binds only to specific amplicons (Osman et al., 2008).

Real-time RT-PCR has been used for detection of viruses that infect different host plants (James et al., 2006), including grapevines (Osman et al., 2007; Pacifico et al., 2011), having higher sensitivity than conventional RT-PCR, overcoming limitations of conventional virus detection systems affected by the erratic distribution of viruses in the host, variations in virus titre throughout the season and type of sampling tissue, as observed in grapevines. Additionally TaqMan probes can be labeled with different fluorophores, excited at different wavelengths, allowing the simultaneous detection of more than one virus species in a single reaction. Multiplex reactions rationalize the use of reagents, decrease the required time for analysis and reduce detection costs (Pallas et al., 2009). Real-time RT-PCR allows pathogen quantification, precision, reproducibility, faster analysis and it is particularly useful because it eliminates the need for post-PCR processing steps (Osman et al., 2012).

In general, viruses have great potential for the generation of genetic variability due to their infectious 
nature that establishes the infectious processes throughout the life cycle of the host, as well as error-prone replication of its genome and the lack of RNA repair mechanisms (Hull, 2004). The significant genetic variability shown by some virus species in grapevines and other hosts hampers the development of sensitive and reliable molecular tools for virus detection and identification. As a consequence, failures in detecting some isolates from a specific geographical region can occur. This emphasizes the need of more sensitive techniques to avoid false negative results (James et al., 2006; Pallas et al., 2009). The aims of this study were to evaluate the efficiency of TaqMan real-time RT-PCR in individual and simultaneous (duplex) reactions for detection of different isolates of ten important viral species that infect grapevines in Brazil.

The positive controls consisted of isolates of Foveavirus: GRSPaV (EF690384), Vitivirus: GVA (AF494187), GVB (AF438410) and GVD (JQ031715), Ampelovirus: GLRaV-1 (GQ332536), GLRaV-3 (AY753208) and GLRaV-5 (JQ821315), Closterovirus: GLRaV-2 (EU053126), Nepovirus: GFLV (EU258680) and Maculavirus: GFkV (JN022610), previously molecularly characterized with GenBank accessions inside brackets. Samples were obtained from different grapevine cultivars, maintained under controlled conditions in a greenhouse. Grapevine accession cv. 1103 Paulsen, obtained through thermotherapy and tissue culture procedures, was used as healthy control of reactions.

The total RNA extractions from scraping of mature stems were performed using adsorption of nucleic acids on silica particles protocol (Rott \& Jelkmann, 2001) and were quantified by spectrophotometry. The total RNA quality was monitored by inclusion of primers and probe for $18 \mathrm{~S}$ rRNA (Osman et al., 2007). In all performed analyses, duplicates of RNAse free water, healthy grapevines and positive controls were included. Primer and probe sets are described in Table 1. For GLRaV-1 three sets of primers and probes were tested: Osman et al. (2007); mixture of Osman et al. (2007) and Klaassen et al. (2011), a wide range reagent targeted to the same viral region; and Pacifico et al. (2011) (Table 1). All probes were labeled with fluorophores 6-FAM or VIC at their 5' end. TAMRA was used as quencher at the 3 ' end to allow detection of two viruses in the same sample or reaction (Table 1).

Real-time RT-PCR reactions (One Step RT-PCR) were carried out in 96-well plates using the kit TaqMan Master Mix One-Step RT-PCR (Applied Biosystems): $6.1 \mu \mathrm{L}$ of the One-Step RT-PCR Master Mix (containing AmpliTaq Gold DNA polymerase, dNTPs, a passive reference ROX and optimized buffer); $0.6 \mu \mathrm{L}$ of the mixture of primers and probe(s) ( $415 \mathrm{nM}$ primer and $85 \mathrm{nM}$ probe); $0.3 \mu \mathrm{L}$ of MuLV reverse transcriptase and RNAse inhibitor and $3 \mu \mathrm{L}$ of total RNA (ca. $300 \mathrm{ng}$ ) to a final volume of $12 \mu \mathrm{L}$. The reactions were performed in a thermocycler StepOnePlus Real-time PCR System (Applied Biosystems) as follows: $45^{\circ} \mathrm{C}$ for $35 \mathrm{~min}$ (for reverse transcription), $95^{\circ} \mathrm{C}$ for $10 \mathrm{~min}$ (activation of AmpliTaq Gold), followed by 40 cycles at $95^{\circ} \mathrm{C}$ for $15 \mathrm{~s} \mathrm{(denaturation)} \mathrm{and} 60^{\circ} \mathrm{C}$ for $1 \mathrm{~min}$ (annealing and extension). The reaction data were analyzed as presence/ absence assays and graphically, using the StepOne Software (Applied Biosystems), by determining the $\mathrm{C}_{\mathrm{T}}$ (threshold cycle). The $\mathrm{C}_{\mathrm{T}}$ is the cycle at which an exponential increase in fluorescence occurs (Osman et al., 2008), hence, in this work it was established that a $\mathrm{C}_{\mathrm{T}}$ value below 35 indicates a positive result. To check the efficiency and reproducibility of reactions resulting from the use of primers and probes, virus-infected control samples and samples with unknown phytosanitary status were analyzed in simplex reactions for all ten viruses evaluated.

Considering the existence of nucleotide sequence variability among isolates, eleven GRSPaV-isolates and three GFLV-isolates, previously characterized (Radaelli et al., 2009; Basso et al., 2010), were submitted to analysis. For these analyses, purified coat protein (CP) DNA fragments (adjusted to $0.01 \mathrm{ng} \mathrm{DNA} / \mu \mathrm{L}$ ) from recombinant plasmids were used. Adittionally, total RNA extracted from 10 plants showing leafroll-symptoms and maintained in a greenhouse were analysed for GLRaV-3 by real-time RT-PCR.

For duplex real-time RT-PCR reactions, the volumes of reagents were adjusted according to the two conditions performed: (1) Duplex with total RNA of virus-infected control sample: $8.1 \mu \mathrm{L}$ of the reagent Master Mix; $0.8 \mu \mathrm{L}$ each of primer and probe mixtures from virus 1 and $2 ; 0.4$ $\mu \mathrm{L}$ MuLV RT and RNase inhibitor and $3 \mu \mathrm{L}$ each of total RNA from controls to a final volume of $16.1 \mu \mathrm{L}$. (2) Duplex with total RNA of samples with unknown phytosanitary status: $6.1 \mu \mathrm{L}$ of the reagent Master Mix; $0.6 \mu \mathrm{L}$ each of primer and probe mixtures from virus 1 and $2 ; 0.3 \mu \mathrm{L}$ MuLV RT and RNase inhibitor and $3 \mu \mathrm{L}$ of total RNA to a final volume of $12 \mu \mathrm{L}$.

In the first situation mentioned above, two virusinfected grapevine accessions (positive controls) were used in a single reaction. In the second situation, several symptomatic grapevines, with unknown sanitary status were tested in single reactions. In both situations, the double detections involved pairwise combinations of reagents for GVA, GRSPaV, GLRaV-2 or GLRaV-3 (VIC probes) with reagents for viruses GVB, GVD, GLRaV-5, GFLV or GFkV (6-FAM probes) (Table 1), in a total of 20 combinations. Also thirty-six Vitis vinifera and V. labrusca species, and grapevine hybrid accessions, previously regenerated after combined sanitation treatment with thermotherapy and tissue culture of heat treated apexes and maintained in suspended beds in a greenhouse were tested by duplex realtime RT-PCR reactions.

Partial nucleotide sequence of GLRaV-1 was amplified by conventional RT-PCR with the same two primer sets used previously (Klaassen et al., 2011, not included) (Table 1). The cDNA synthesis, PCR reactions, cloning, purification and sequencing of amplified fragments (two-three clones of each) were performed as described by Basso et al. (2010). Total RNA was extracted from cv. Petit 
C.R. Dubiela et al.

TABLE 1 - Primer and probe sets tested in real-time RT-PCR detections of grapevine viruses

\begin{tabular}{|c|c|c|c|c|c|c|}
\hline Virus & $\begin{array}{c}\text { Primer and } \\
\text { probe }\left({ }^{*}\right)\end{array}$ & $\begin{array}{c}\text { Fluorophore / } \\
\text { quencher }\end{array}$ & Orientation & Target gene & $\begin{array}{l}\text { Fragment } \\
\text { size (bp) }\end{array}$ & Reference \\
\hline \multirow[t]{8}{*}{ GRSPaV } & RSPaV-52 F1 & --- & F & $\mathrm{CP}$ & 102 & Osman \& Rowhani (2008) \\
\hline & RSPaV-52 F2 & ---- & $\mathrm{F}$ & & & \\
\hline & RSPaV-52 F3 & ---- & F & & & \\
\hline & RSPaV-130 R1 & ---- & $\mathrm{R}$ & & & \\
\hline & RSPaV-130 R2 & --- & $\mathrm{R}$ & & & \\
\hline & RSPaV-75 P1 & VIC / TAMRA & $\mathrm{P}$ & & & \\
\hline & RSPaV-75 P2 & VIC / TAMRA & $\mathrm{P}$ & & & \\
\hline & RSPaV-75 P3 & VIC / TAMRA & $\mathrm{P}$ & & & \\
\hline \multirow[t]{5}{*}{ GVA } & GVA-77 F1 & --- & $\mathrm{F}$ & $\mathrm{CP}$ & 115 & Osman \& Rowhani (2008) \\
\hline & GVA-77 F2 & ---- & $\mathrm{F}$ & & & \\
\hline & GVA-192 R1 & ---- & $\mathrm{R}$ & & & \\
\hline & GVA-192 R2 & --- & $\mathrm{R}$ & & & \\
\hline & GVA-104 P & VIC / TAMRA & $\mathrm{P}$ & & & \\
\hline \multirow[t]{7}{*}{ GVB } & GVB-92 F1 & ---- & $\mathrm{F}$ & $\mathrm{CP}$ & 110 & Osman \& Rowhani (2008) \\
\hline & GVB-92 F2 & ---- & $\mathrm{F}$ & & & \\
\hline & GVB-92 F3 & ---- & $\mathrm{F}$ & & & \\
\hline & GVB-202 R1 & ---- & $\mathrm{R}$ & & & \\
\hline & GVB-202 R2 & --- & $\mathrm{R}$ & & & \\
\hline & GVB-119 P1 & 6-FAM / TAMRA & $\mathrm{P}$ & & & \\
\hline & GVB-119 P2 & 6-FAM / TAMRA & $\mathrm{P}$ & & & \\
\hline \multirow[t]{3}{*}{ GVD } & GVD-554 F & --- & $\mathrm{F}$ & $\mathrm{CP}$ & 78 & Osman \& Rowhani (2008) \\
\hline & GVD-631 R & --- & $\mathrm{R}$ & & & \\
\hline & GVD-580 P & 6-FAM / TAMRA & $\mathrm{P}$ & & & \\
\hline \multirow[t]{3}{*}{ GLRaV-1 } & LR1 HSP70-149 F & --- & $\mathrm{F}$ & HSP70 & $145^{(* *)}$ & Osman et al. (2007) \\
\hline & LR1 HSP70-293 R & --- & $\mathrm{R}$ & & & \\
\hline & LR1 HSP70-225 P & 6-FAM / TAMRA & $\mathrm{P}$ & & & \\
\hline \multirow[t]{3}{*}{ GLRaV-1 } & LR1-149 f2 & --- & $\mathrm{F}$ & HSP70 & $145^{(* *)}$ & Klaassen et al. (2011) \\
\hline & LR1-149 f3 & --- & $\mathrm{F}$ & & & \\
\hline & LR1-225 p2 & 6-FAM / TAMRA & $\mathrm{P}$ & & & \\
\hline \multirow[t]{3}{*}{ GLRaV-1 } & GLRaV1Ppoly167 F & ---- & $\mathrm{F}$ & $\mathrm{RdRp}$ & 60 & Pacifico et al. (2011) \\
\hline & GLRaV1Ppoly206 R & ---- & $\mathrm{R}$ & & & \\
\hline & GLRaV1Ppoly190 P & 6-FAM / TAMRA & $\mathrm{P}$ & & & \\
\hline \multirow[t]{3}{*}{ GLRaV-2 } & GLRaV-2 $198 \mathrm{~F}$ & $\begin{array}{ll}--- \\
--\end{array}$ & $F$ & HSP70 & 116 & Osman et al. (2007) \\
\hline & GLRaV-2 $290 \mathrm{R}$ & ---- & $\mathrm{R}$ & & & \\
\hline & GLRaV-2 233 P & VIC / TAMRA & $\mathrm{P}$ & & & \\
\hline \multirow[t]{3}{*}{ GLRaV-3 } & GLRaV-3 $56 \mathrm{~F}$ & ---- & $\mathrm{F}$ & HSP70 & 254 & Osman et al. (2007) \\
\hline & GLRaV-3 $285 \mathrm{R}$ & --- & $\mathrm{R}$ & & & \\
\hline & GLRaV-3 $181 \mathrm{P}$ & VIC / TAMRA & $\mathrm{P}$ & & & \\
\hline \multirow[t]{3}{*}{ GLRaV-5 } & GLRaV5 HSP-26 F & --- & $\mathrm{F}$ & HSP70 & 162 & Osman et al. (2007) \\
\hline & GLRaV5 HSP-188 R & --- & $\mathrm{R}$ & & & \\
\hline & GLRaV5 HSP-131 P & 6-FAM / TAMRA & $\mathrm{P}$ & & & \\
\hline \multirow[t]{5}{*}{ GFkV } & Fleck $239 \mathrm{~F}$ & --- & $\mathrm{F}$ & $\mathrm{RdRp}$ & 89 & Osman et al. (2008) \\
\hline & Fleck 328 R & ---- & $\mathrm{R}$ & & & \\
\hline & Fleck 261 P1 & 6-FAM / TAMRA & $\mathrm{P}$ & & & \\
\hline & Fleck 261 P2 & 6-FAM / TAMRA & $\mathrm{P}$ & & & \\
\hline & Fleck 261 P3 & 6-FAM / TAMRA & $\mathrm{P}$ & & & \\
\hline \multirow[t]{3}{*}{ GFLV } & GFLV $769 \mathrm{~F}$ & ---- & $\mathrm{F}$ & $\mathrm{CP}$ & 99 & Osman \& Rowhani (2006) \\
\hline & GFLV $868 \mathrm{R}$ & ---- & $\mathrm{R}$ & & & \\
\hline & GFLV 799 P & 6-FAM / TAMRA & $\mathrm{P}$ & & & \\
\hline
\end{tabular}

\footnotetext{
(*) Original primer and probe nomenclature was maintained as published

${ }^{(* *)}$ Corresponding to the same amplified fragment.

- $\mathrm{F}=$ forward primer, $\mathrm{R}=$ reverse primer, $\mathrm{P}=$ fluorescent probe.

- CP (coat protein), HSP70 (heat shock protein 70), RdRp (RNA dependent RNA polymerase)
} 
Syrah (PS isolate, GQ332536 in GenBank). The nucleotide sequences were aligned using the software ClustalX 1.8. Comparisons between the obtained nucleotide sequences and other viral sequences available in the GenBank were performed using the BLASTn program at the NCBI site.

The detection by simplex real-time RT-PCR (TaqMan) was accurate and consistent, and the $\mathrm{C}_{\mathrm{T}}$ values were compatible with the presence of viruses in the samples and positive controls. The shape of the curves obtained during the amplifications were as expected for virus amplifications, as was obtained for GFkV (Figure 1A). The lowest and highest $\mathrm{C}_{\mathrm{T}}$ values obtained for each virus were: GLRaV-2 (17.1 to 35.0), GLRaV-3 (17.9 to 27.1), GVA (16.7 to 34.0), GVB (14.6 to 32.2), GRSPaV (19.6 to 28.3), GFLV (15.7 to 28.9), GFkV (19.9 to 32.6), GVD (18.9 to 33.6), GLRaV-5 (24.7 to 26.9), considering ten tested samples and controls. $\mathrm{C}_{\mathrm{T}}$ values are related to the viral titer in the analised sample; therefore, a lower $\mathrm{C}_{\mathrm{T}}$ means higher viral titer. No positive $\mathrm{C}_{\mathrm{T}}$ values were obtained in assays of total RNA from healthy grapevines or RNAse free water. Primers and probes and reaction conditions were adequate for detecting isolates of mentioned viruses. The accurate amplification of these
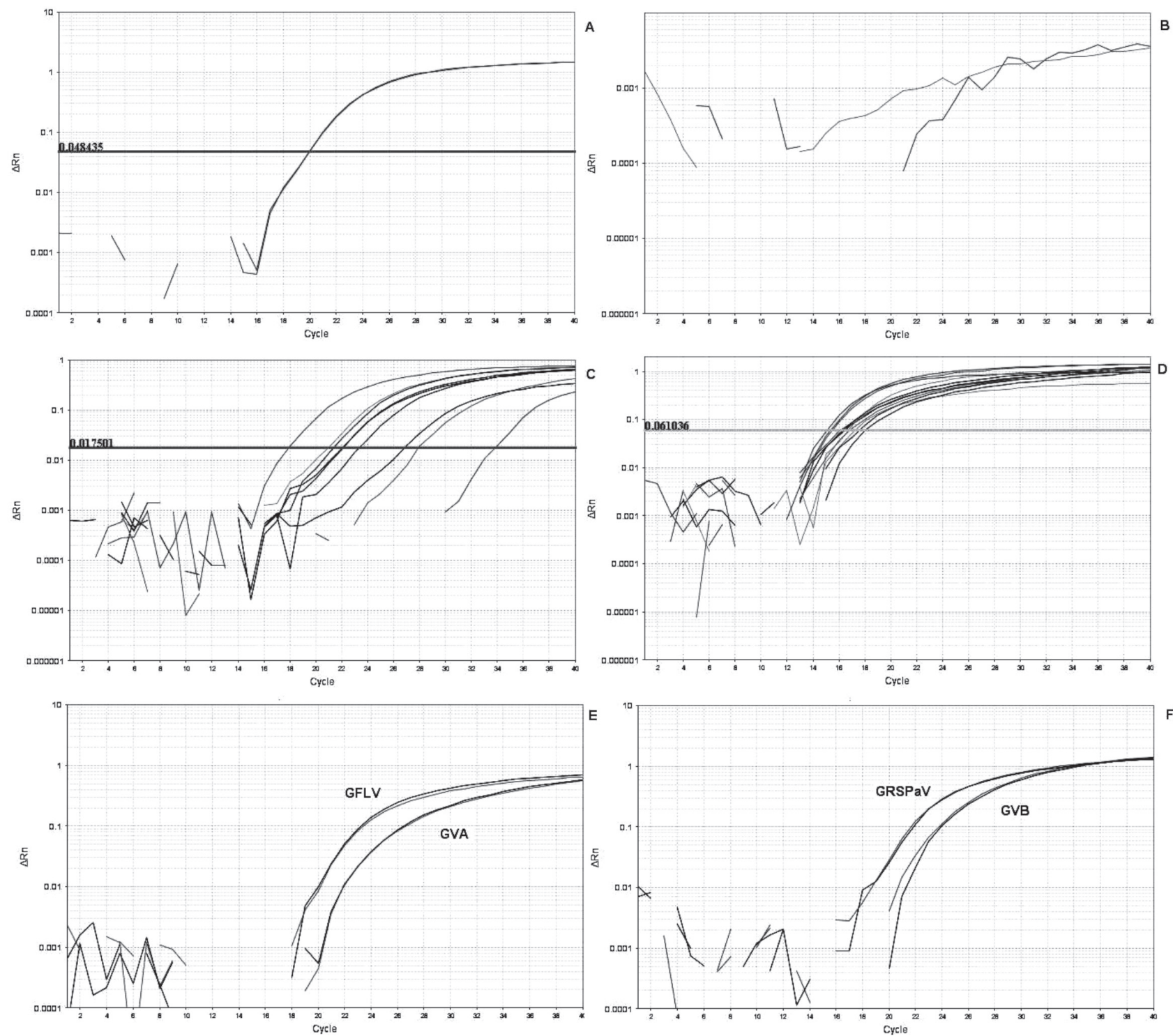

FIGURE 1 - Graphical amplification results by real-time RT-PCR (TaqMan). A. Curves of the simplex real-time RT-PCR of GFkV, cv. Benefuji; B. GLRaV-1, cv. Petit Syrah (with primers and probe designed only by Osman et al., 2007); C. Amplification curves of nine GLRaV-3 infected samples; D. Eleven GRSPaV isolates (cDNA at $0.01 \mathrm{ng}$ DNA/ $\mu \mathrm{L}$ ); E. Curves of duplex analysis from two infected samples; F. Curves of duplex analysis of two viruses from a single sample, double infected plants; A, B, E and F show the duplicate tests (curves). The horizontal line indicates the threshold and intersection of this line with the curve determines the $\mathrm{C}_{\mathrm{T}}$ value in the $\mathrm{X}$ axis. $\mathrm{Y}$ axis $(\Delta \mathrm{Rn}=$ normalized fluorescence intensity) and $\mathrm{X}$ axis (number of cycles). 
viruses is relevant considering the significant variabilities as was previously reported for several grapevine virus (Martelli, 2012; Basso et al., 2010).

However the test failed to detect GLRaV-1 local isolates, resulting in curves with uncharacteristic design ("zig-zag" shape) (Figure 1B) obtained with primer pairs and probes targeting the HSP70 (Osman et al., 2007) and the RdRp coding genes (Pacifico et al., 2011) (Table 1), probably due to insufficient primer/probes homology to local isolates. Otherwise, it was possible to amplify GLRaV-1, including PS isolate, $\mathrm{C}_{\mathrm{T}}$ value 20 (data not shown), using a mixture of primers and probes, defined by Osman et al. (2007) and Klaassen et al. (2011). Certainly this specific reagent set may have expanded the range of detectable isolates by considering more nucleotide variations, in the same position of the target, during primer/probe design procedures.

Fajardo et al. (2011) characterized the PS isolate of GLRaV-1 (the same included in this work), finding CP gene nucleotide identities ranging from 89.1 to $94.5 \%$ with five foreign isolates of GLRaV-1. The genetic diversity of several isolates of GLRaV-1 was investigated by Alabi et al. (2011) based on segments of the HSP70, CP, CP duplicate 2 (CPd2) and ORF9, revealing intra- and inter-isolate sequence diversity of CPd2 and HSP70. This study indicated different purifying selection pressures acting on each of the four genomic regions. A global phylogenetic analysis of sequences from the four genomic regions revealed segregation of GLRaV-1 isolates into three major clades and a lack of clearly defined clustering by geographical origin. Putative recombination events were revealed among the HSP70, CP and ORF9 sequences. This GLRaV-1 variability may explain the present negative/positive detection results.

Divergences in nucleotide identities among local and foreign viral species as mentioned in previously published reports, have not been established at the pairing sites of primers and probes used here. Thus, the variability among grape viruses possesses high relevance and should be considered for a precise design of diagnostic tools.

Primers and probes for GLRaV-3 could detect the virus in nine out of ten grapevine accessions with leafroll symptoms, with $\mathrm{C}_{\mathrm{T}}$ values ranging from 17.9 to 33.9 , demonstrating their suitability to detect a broad range of GLRaV-3 isolates (Figure 1C). The genetic diversity of GLRaV-3 has been demonstrated (Gouveia et al., 2011), based on the analysis of the capsid protein or heat shock 70 (HSP70) genes, which revealed the existence of three to five phylogenetic groups in the populations of this virus.

The detection of several isolates of GRSPaV and GFLV by real-time RT-PCR (TaqMan), reveals the high efficiency of primers and probes to detect viral cloned cDNA, previously characterized (Radaelli et al, 2009; Basso et al., 2010). The $\mathrm{C}_{\mathrm{T}}$ values for eleven $\mathrm{GRSPaV}$ isolates (Figure 1D) and three GFLV isolates ranged from 15 to 18.1 and from 17.8 to 18.6 , respectively, with no significant differences in detection efficiency among the isolates, as indicated by the shape and range of the detection curve (Figure 1D). Analysis based on cloned cDNA of GRSPaV and GFLV allowed to standardize template concentration, representing individual characterized isolates of these two viruses, as compared to the bulk character of plant extracts for GLRaV-3 detection.

Radaelli et al. (2009) characterized the CP gene of nine $\mathrm{GRSPaV}$ isolates included in this study, observing nucleotide identities ranging from 81.1 to $99.7 \%$ among them. Basso et al. (2010) performed a similar study, with two isolates, also included in this study, observing nucleotide identity of $84.7 \%$ between them. Finally, Radaelli et al. (2009) observed CP nucleotide identities ranging from 89.8 to $99.2 \%$ among three GFLV isolates, included in this study. All above mentioned isolates also showed high nucleotide identity (>90\%) with some previously characterized foreign isolates.

Duplex real-time RT-PCR reactions either from different plants or from an individual, double infected plant, successfully detected the viruses mentioned before (GLRaV-1 not included), resulting in $\mathrm{C}_{\mathrm{T}}$ values within the technically recommended range, with maximum $\mathrm{C}_{\mathrm{T}}$ of 35 . In this work, most of the $\mathrm{C}_{\mathrm{T}}$ values ranged from 15 to 25 (Table 2). $\mathrm{C}_{\mathrm{T}}$ values above 35 may represent nonspecific reactions. The Figure 1E shows the graphical output of these reactions, illustrating the simultaneous GFLV and GVA detection from different plants. In this specific case, two virus-infected plants were used with distinct and previously identified viruses. The results of the simultaneous detection from individual, double infected plants, are illustrated in Figure 1F for GRSPaV and GVB. In both cases, the double detection from two positive controls or from a single double infected sample, generated accurate, sensitive and reproducible results. Each individual amplification reaction in a duplex assay must work under identical conditions, avoiding competition for reagents or inhibition between the individual reactions. In an optimized multiplex reaction the results of multiplex PCR are similar to those obtained from individual reactions for each target (James et al., 2006), such as was verified in this work.

Thirty six assayed grapevine accessions revealed a few plants with residual virus infections, the highest incidence being of GRSPaV (five accessions), a virus recalcitrant to sanitation treatments (Martelli, 2012), followed by GVA (two accessions) and GVB, GLRaV-2 and GLRaV-3 (one accession each virus). The samples were free of GVD, GLRaV-5, GFLV and GFkV.

Only very recently there were reports of the simultaneous detection of different grapevine viruses using real-time RT-PCR (Olmos et al., 2012; Osman et al., 2012). Osman et al. (2012) developed a single quantitative multiplex real-time PCR assay to detect GVA, GVB and GVD, and Olmos et al. (2012) developed multiplex realtime RT-PCR based on TaqMan to assess prevalence of GFLV, ArMV, GFkV, GLRaV-1 and GLRaV-3 in Spain. In our work we report simultaneous, one-tube-detection of 
TABLE 2 - Results $\left(\mathrm{C}_{\mathrm{T}}\right)$ of duplex real-time RT-PCR, using two virus-infected plants (controls) or by analysing double infected plants of unknown previous phytosanitary status

\begin{tabular}{|c|c|c|c|c|c|}
\hline \multicolumn{3}{|c|}{$\begin{array}{l}\text { Two virus-infected plants } \\
\text { (controls) }\end{array}$} & \multicolumn{3}{|c|}{$\begin{array}{c}\text { Single sample } \\
\text { (double infected plants with previously unknown } \\
\text { phytosanitary status) }\end{array}$} \\
\hline $\begin{array}{l}\text { Description of the } \\
\text { samples }\end{array}$ & Virus & $C_{T}$ values & $\begin{array}{l}\text { Description of the } \\
\text { samples }\end{array}$ & Virus & $C_{T}$ values \\
\hline \multirow{2}{*}{$\begin{array}{l}\text { Italia } \\
\text { LN33 }\end{array}$} & GVA & 27.7 & \multirow[t]{2}{*}{ BRS Cora } & GVA & 24.6 \\
\hline & GVB & 20.2 & & GVB & 19.7 \\
\hline \multirow{2}{*}{$\begin{array}{l}\text { Italia } \\
\text { Rupestris du Lot }\end{array}$} & GVA & 23.1 & \multirow[t]{2}{*}{ Rupestris du Lot } & GVA & 19.0 \\
\hline & GFLV & 21.4 & & GFLV & 17.1 \\
\hline \multirow{2}{*}{$\begin{array}{l}\text { Italia } \\
\text { Benefuji }\end{array}$} & GVA & 35.0 & \multirow[t]{2}{*}{ Italia } & GVA & 31.7 \\
\hline & GFkV & 14.5 & & GFkV & 16.5 \\
\hline \multirow{2}{*}{$\begin{array}{l}\text { Cabernet Franc } \\
\text { LN33 }\end{array}$} & GRSPaV & 20.5 & \multirow[t]{2}{*}{ Dolcetto } & GVA & 16.7 \\
\hline & GVB & 22.5 & & GVD & 20.2 \\
\hline \multirow{2}{*}{$\begin{array}{l}\text { Cabernet Franc } \\
\text { Rupestris du Lot }\end{array}$} & GRSPaV & 22.4 & \multirow[t]{2}{*}{ Cabernet Franc } & GRSPaV & 20.6 \\
\hline & GFLV & 22.1 & & GVB & 23.7 \\
\hline \multirow{2}{*}{$\begin{array}{l}\text { Cabernet Franc } \\
\text { Benefuji }\end{array}$} & GRSPaV & 17.6 & \multirow[t]{2}{*}{ Italia (sample 1) } & GRSPaV & 29.1 \\
\hline & GFkV & 15.6 & & GFLV & 22.9 \\
\hline \multirow{2}{*}{$\begin{array}{l}\text { Cabernet Franc } \\
\text { Dolcetto }\end{array}$} & GRSPaV & 23.6 & \multirow[t]{2}{*}{ Italia (sample 16) } & GRSPaV & 24.3 \\
\hline & GVD & 21.1 & & GFkV & 28.8 \\
\hline \multirow{2}{*}{$\begin{array}{l}\text { Isabel } \\
\text { LN33 }\end{array}$} & GLRaV-2 & 26.9 & \multirow[t]{2}{*}{ Cardinal } & GRSPaV & 28.0 \\
\hline & GVB & 22.7 & & GLRaV-5 & 27.9 \\
\hline \multirow{2}{*}{$\begin{array}{l}\text { Isabel } \\
\text { Rupestris du Lot }\end{array}$} & GLRaV-2 & 26.9 & \multirow[t]{2}{*}{ Dolcetto } & GRSPaV & 23.2 \\
\hline & GFLV & 22.0 & & GVD & 21.6 \\
\hline \multirow{2}{*}{$\begin{array}{l}\text { Isabel } \\
\text { Benefuji }\end{array}$} & GLRaV-2 & 15.5 & \multirow[t]{2}{*}{ Isabel } & GLRaV-2 & 24.0 \\
\hline & GFkV & 15.7 & & GVB & 21.6 \\
\hline \multirow{2}{*}{$\begin{array}{l}\text { Isabel } \\
\text { Dolcetto }\end{array}$} & GLRaV-2 & 19.7 & \multirow[t]{2}{*}{ Rupestris du Lot } & GLRaV-2 & 17.1 \\
\hline & GVD & 21.2 & & GFLV & 15.6 \\
\hline \multirow{2}{*}{$\begin{array}{l}\text { Cabernet Franc } \\
\text { LN33 }\end{array}$} & GLRaV-3 & 18.5 & \multirow[t]{2}{*}{ Itália (sample 17) } & GLRaV-2 & 28.9 \\
\hline & GVB & 13.1 & & GFkV & 32.7 \\
\hline \multirow{2}{*}{$\begin{array}{l}\text { Cabernet Franc } \\
\text { Rupestris du Lot }\end{array}$} & GLRaV-3 & 24.4 & \multirow[t]{2}{*}{ Itália (sample 1) } & GLRaV-3 & 20.0 \\
\hline & GFLV & 13.9 & & GVD & 28.5 \\
\hline \multirow{2}{*}{$\begin{array}{l}\text { Petit Syrah } \\
\text { Dolcetto }\end{array}$} & GLRaV-3 & 27.2 & \multirow{2}{*}{$\begin{array}{l}\text { Grapevine } \\
\text { (accession 33) }\end{array}$} & GRSPaV & 29.4 \\
\hline & GVD & 21.7 & & GLRaV-5 & 27.9 \\
\hline
\end{tabular}

two grapevine local virus isolates, using real-time RT-PCR (TaqMan).

Sequences of two fragments of GLRaV-1 of 60 and $145 \mathrm{bp}$, corresponding to RdRp and HSP70 partial coding regions, were aligned with primer and probe sequences (Table 1) as well as with GLRaV-1 sequences of GenBank revealing a divergence of the Brazilian isolate PS of one nucleotide $(\mathrm{C} \rightarrow \mathrm{A})$ at position 26 , in relation to the probe sequence (LR1190P) (Figure 2A). Another divergence $(\mathrm{C} \rightarrow \mathrm{T})$ was found between the probe and two GLRaV-1 isolates (EF103901 and AF195822) at same position. In the second alignment (Figure 2B), there were two divergences in relation to the probe sequence HSP70-225P: at position $87(\mathrm{~T} \rightarrow \mathrm{A})$, isolates PS, AF195822 and EF103901, and at position $90(\mathrm{G} \rightarrow \mathrm{A})$, isolates PS and AF195822.

Considering the complete identity of the obtained sequences and their respective primers, failures in the detection of GLRaV-1 isolate could be probably related to the partial homologies of probes and their viral homologous pairing regions (Figure 2A, 2B). Recently, Klaassen et al. (2011) performed a survey for several grapevine viruses using realtime PCR. The probe LR1-225p2 diverges from probe LR1 HSP70-225P by a single nucleotide (Figure 2B). As a result of this change, the LR1-225p2 probe became more homologous to the $145 \mathrm{bp}$ fragment of the Brazilian PS isolate (Figure 2B), definitely contributing to GLRaV-1 isolate PS detection. Especially for RNA viruses, probe-based assays can fail to recognize all characterized virus variants (isolates, strains or subgroups). This is particularly true when mutation or nucleotide substitution occurs within the probe pairing site, resulting in false-negative (James et al., 2006).

Marbot et al. (2004) demonstrated that a mismatch of a single nucleotide between probe and the target viral sequence may prevent the fluorogenic reaction from proceeding. Sequencing of a large number of isolates may allow the design of probes in more conserved regions. Alternatively MGB probes should be considered to avoid false negatives by reducing the 
A

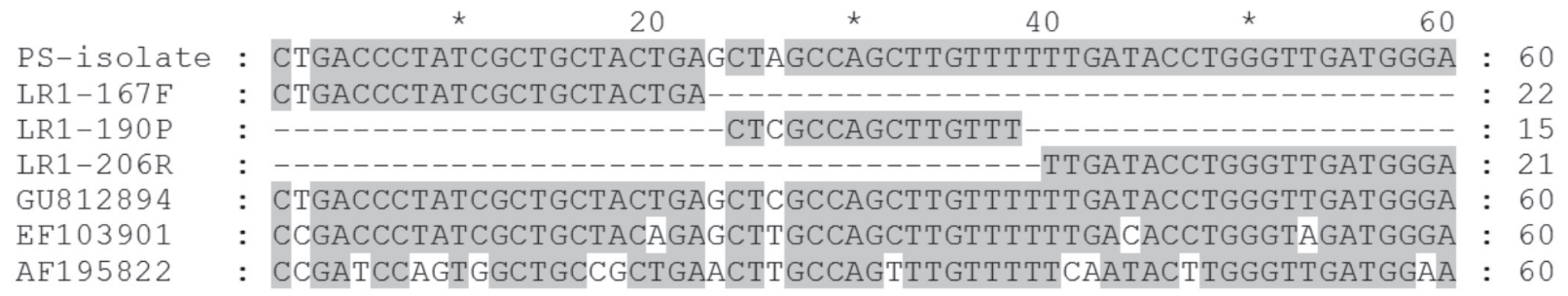

B
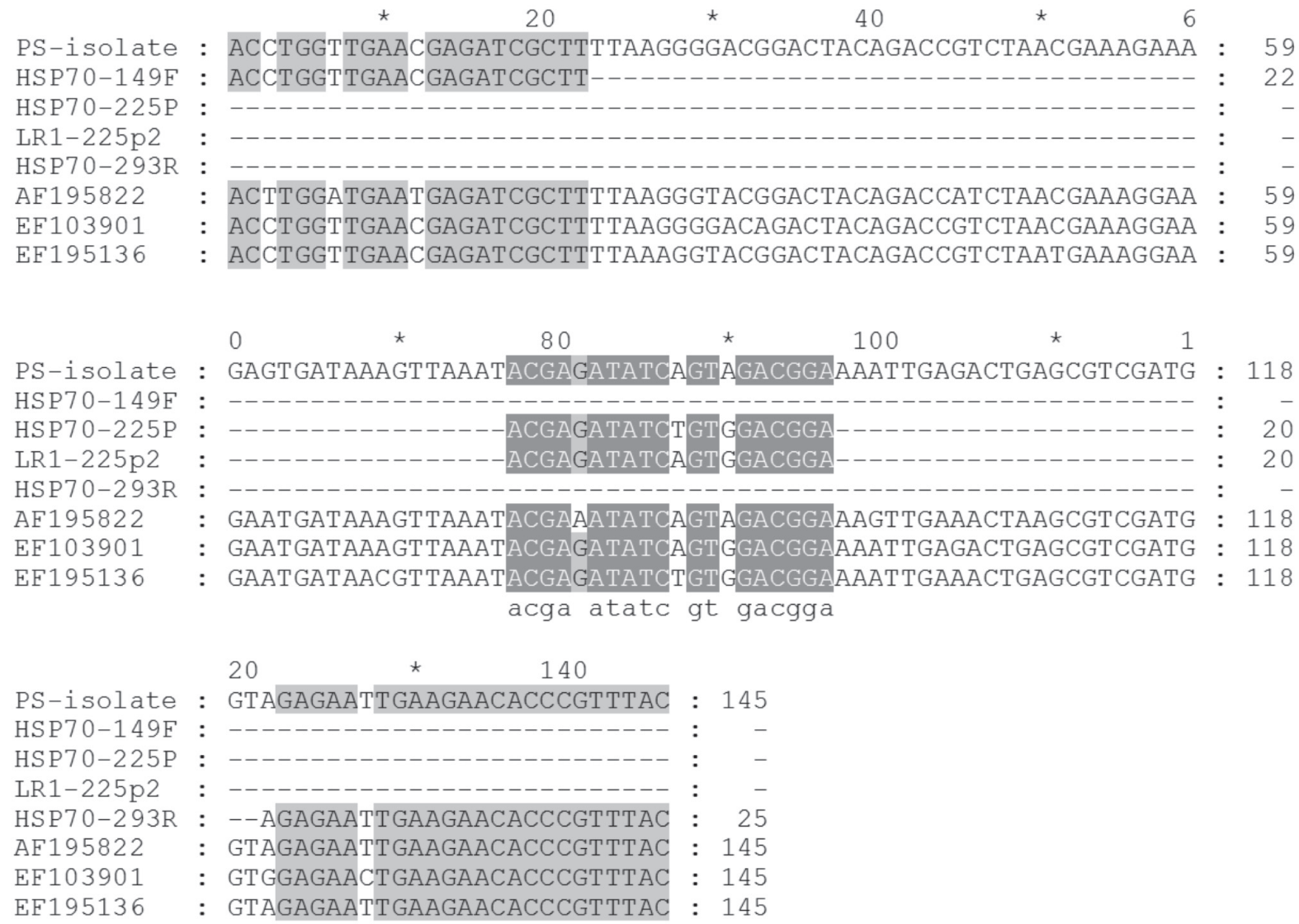

FIGURE 2 - A. Multiple nucleotide sequence alignments of the partial RNA dependent RNA polymerase gene (60 bp) of Grapevine leafroll-associated virus 1 (GLRaV-1); B. and partial sequence of GLRaV-1 HSP70 gene (145 bp); GLRaV-1 Brazilian, PS isolate; the primer and probe sequences (Table 1), and GLRaV-1 isolates deposited in the GenBank database (GU812894: Italy; EF103901: South Africa; AF195822: Australia, EF195136: USA).

size of the probe (Marbot et al., 2004; Osman et al., 2007). Virus detection through real-time RT-PCR (TaqMan) has been confirmed to be highly sensitive, specific and robust, being able to detect different viruses from collected samples in Brazilian vineyards. Its execution is fast, reliable, only slightly laborious and attractive in terms of cost-benefit. It was particularly suitable for testing several viruses in a large number of samples, especially in the duplex format. The implementation of real-time RT-PCR (TaqMan), supported by molecular characterization of divergent isolates, as was tentatively shown for GLRaV-1, would help to increase the scope of the diagnosis of grapevine infecting viruses.

\section{ACKNOWLEDGMENTS}

To Conselho Nacional de Desenvolvimento Científico e Tecnológico - CNPq - Brazil for financial support. To Vanessa Buffon and Marcos Vanni for technical assistance.

\section{REFERENCES}

Alabi OJ, Rwahnih MA, Karthikeyan G, Poojari S, Fuchs M, Rowhani A, Naidu RA (2011) Grapevine leafroll-associated 
virus 1 occurs as genetically diverse populations. Phytophatology 101:1446-1456.

Basso MF, Fajardo TVM, Eiras M, Ayub RA, Nickel O (2010) Detecção e identificação molecular de vírus associados a videiras sintomáticas e assintomáticas. Ciência Rural 40:2249-2255.

Fajardo TVM, Nickel O, Eiras M (2011) Detecção e caracterização molecular dos genes da proteína capsidial de ilarvirus e ampelovirus que infectam fruteiras temperadas. Ciência Rural 41:5-9.

Gouveia P, Santos MT, Eiras-Dias JE, Nolasco G (2011) Five phylogenetic groups identified in the coat protein gene of Grapevine leafroll-associated virus 3 obtained from Portuguese grapevine varieties. Arquives of Virology 156:413-420.

Hull R (2004) Matthews' Plant Virology. $4^{\text {th }}$ Ed. San Diego. Elsevier Academic Press.

James D, Varga A, Pallas V, Candresse T (2006) Strategies for simultaneous detection of multiple plant viruses. Canadian Journal of Plant Pathology 28:16-29.

Klaassen VA, Sim ST, Dangl GS, Osman F, Al Rwahnih M, Rowhani A, Golino DA(2011) Vitis californica and Vitis californica $\times$ Vitis vinifera hybrids are hosts for Grapevine leafroll-associated virus-2 and -3 and Grapevine virus $A$ and B. Plant Disease 95:657665.

Marbot S, Kummert J, Salmon M, Vendrame M, Dutrecq O, Lepoivre P (2004) Development of RT-PCR assays using fluorogenic 3' minor groove binder DNA probes for detection of fruit tree viruses. Acta Horticulturae 657:547-551.

Martelli GP (2012) Grapevine virology highlights 2010-2012. In: $17^{\text {th }}$ Congress of the International Council for the Study of Virus and Virus-like Diseases of the Grapevine, Proceedings... Davis USA. pp.13-31.

Olmos A, Borrás MC, Bertolini E, García J, Gisbert C, Yuste A, Wetzel T, Cambra M (2012) Multiplex real-time RT-PCR for estimation of the prevalence of the main five grapevine viruses infecting wine and table grapes in Alicante, Spain. In: $17^{\text {th }}$ Congress of the International Council for the Study of Virus and Virus-like Diseases of the Grapevine, Proceedings... Davis USA. pp. 216-217.
Osman F, Leutenegger C, Golino D, Rowhani A (2007) Real-time RT-PCR (TaqMan) assays for the detection of Grapevine leafroll associated viruses 1-5 and 9. Journal of Virological Methods 141:22-29.

Osman F, Leutenegger C, Golino D, Rowhani A(2008) Comparison of low-density arrays, RT-PCR and real-time TaqMan RT-PCR in detection of grapevine viruses. Journal of Virological Methods 149:292-299.

Osman F, Omanska-Klusek A, Olineka T, Hodzic E, Rowhani A (2012) Development and validation of a multiplex quantitative PCR assay for the rapid detection of grapevine vitivirus A, B and D. In: $17^{\text {th }}$ Congress of the International Council for the Study of Virus and Virus-like Diseases of the Grapevine, Proceedings... Davis USA. pp.128-129.

Osman F, Rowhani A (2006) Application of a spotting sample preparation technique for the detection of pathogens in woody plants by RT-PCR and real-time RT-PCR (TaqMan). Journal of Virological Methods 133:130-136.

Osman F, Rowhani A (2008) Real-time RT-PCR (TaqMan) assays for the detection of viruses associated with Rugose wood complex of grapevine. Journal of Virological Methods 154:69-75.

Pacifico D, Caciagli P, Palmano S, Mannini F, Marzachi C (2011) Quantitation of GLRaV-1 and -3, GVA, GFLV and GFkV in field-collected Vitis vinifera L. 'Nebbiolo' by real-time reverse transcription-PCR. Journal of Virological Methods 172:1-7.

Pallas V, Sanchez-Navarro J, Varga A, Aparicio F, James D (2009) Multiplex polymerase chain reaction (PCR) and real-time multiplex PCR for the simultaneous detection of plant viruses. Methods in Molecular Biology 508:193-208.

Radaelli P, Fajardo TVM, Nickel O, Eiras M, Pio-Ribeiro G (2009) Variabilidade do gene da proteína capsidial de três espécies virais que infectam videiras no Brasil. Tropical Plant Pathology 34:297-305.

Rott ME, Jelkmann W (2001) Characterization and detection of several filamentous viruses of cherry: Adaptation of an alternative cloning method (DOP-PCR) and modification of an RNA extraction protocol. European Journal of Plant Pathology 107:411-420. 